\title{
REKAYASA GEOTEKNIK UNTUK PENANGANAN SQUEEZING FAILURE DAN PENEMBUSAN AREA AMBRUKAN ${ }^{1}$
}

\author{
Bagaskara Widi Nugroho'), Suparjono $^{2)}$, Ryan Pratama ${ }^{2)}$ \\ ${ }^{2)}$ Geotechnical Department, Unit Bisnis Pertambangan Emas Pongkor, PT ANTAM Tbk
}

\begin{abstract}
ABSTRAK
Tambang emas bawah tanah UBPE Pongkor terletak di Kawasan Bayah Dome, Jawa Barat, dengan tipe endapan vein system. Sistem penambangan dilakukan dengan system cut and fill dimana upaya penembusan bijih dilakukan dengan drifting. Salah satu tambang yang memiliki kadar tinggi yaitu di area Tambang Ciurug L600 bagian Central dimana batuan di daerah tersebut memilki karakter high altered dan very weak rock strength sehingga mudah runtuh dan berpotensi untuk squeezing. Area XC 662 merupakan salah satu front yang memilki kadar Au tinggi, namun kondisi batuan yang lunak selalu menjadi permasalahannya. Dalam artikel ini akan dibahas dua cara penanganan front yang sudah dilakukan tim Geoteknik UBPE Pongkor. Kasus pertama pada XC 662 yaitu penanganan geoteknik pada batuan lemah teralterasi argilik kuat dengan tipe runtuhan squeezing failure menggunakan pendekatan Convergent Confinement. Kasus kedua pada XC 662.1 yaitu upaya penembusan pada material ambrukan (rubble material) pada heading yang sudah ditinggalkan kemudian dilakukan penembusan kembali menggunakan pendekatan teknis sederhana yang direncanakan dengan matang dan aman (Professional Judgement, Safe, and Well-Planned Method). Kasus di kedua heading ini memiliki persamaan yaitu stand-up time yang sedikit sehingga potensi delay produksi menjadi pertimbangan. Berdasarkan hasil analisis, ground support di XC 662 menggunakan kombinasi antara shotcrete setebal $15 \mathrm{~cm}$ dan cable bolt spasi 1,5 x 1,5 m. Maximum support pressure yang dihasilkan sebesar 2,90 MPa untuk menahan tegangan sebesar 2,16 MPa dengan nilai FS = 1,34. Ground support pada XC 662.1 menggunakan shotcrete yang diaplikasikan secara in-cycle setiap aktivitas penggalian material ambrukan, forepolling pipa spilling $6 \mathrm{~m}$, batang bor, dan bantalan kayu stapling. Pemasangan pipa spilling dan batang bor dilakukan dengan spasi 20-30 cm. Bantalan kayu stapling dipasang di bagian atas forepolling untuk menghindari kontak langsung antara material ambrukan dengan pipa spilling dan batang bor. Desain ground support ini berfungsi baik untuk meningkatkan nilai kohesi pada material ambrukan dan memperpanjang stand-up time. Dari kedua kasus ini diambil kesimpulan bahwa penanganan geoteknik pada heading dengan kondisi very weak rock strength dan high altered harus dilakukan secara in-cycle dan tidak membiarkan span terlalu lama berdiri tanpa penyanggaan.
\end{abstract}

Kata kunci : Cut and fill ; squeezing failure ; material ambrukan ; Convergent Confinement ; Professional Judgement

\begin{abstract}
UBPE Pongkor underground gold mine was placed at physiography of Bayah Dome, West Java, which is have vein system gold deposit. It using cut and fill mining system which using drifting mechanism for getting the ore. One of the highest grade mine location was at Ciurug L 600 Central area which have high altered and very weak rock strength characteristics so that easy to failure and have squeezing potential. XC 662 area was the other highest Au grade mine, but have the problem with the rock mass condition. This article will explain two ways about how to solve its problem which is UBPE Pongkor Geotechnical team was did it. First case at XC 662 was the engineering of squeezing failure which has very weak rock-high argillic altered by Convergent Confinement approachment. The second was placed at XC 662.1 is the engineering of rubble material support at the abandoned heading with the Professional Judgement, Safe, and Well-Planned Method approachment. This two headings have low
\end{abstract}


stand-up time so that potential to making production delay. Based on analysis, the ground support of $X C 662$ using $15 \mathrm{~cm}$ shotcrete and 1,5x1,5 $\mathrm{m}$ cable bolt so that making the maximum support pressure are 2,90 MPa to supporting 2,16 MPa pressure with $F S=1,34$. The ground support of XC 662.1 using in-cycle shotcrete after mucking activities, 6m-spilling pipe forepolling, drilling rod, and wood stapling. The forepolling pipe applied with $20-30 \mathrm{~cm}$ spacing. Stapling wood applied above the forepolling to prevent the rubble material and spilling pipe-drilling rod contact. Its Ground support design was well-function to improved the rubble material cohesion and increase the stand-up time. The conclusion of this cases are geotechnical engineering design at very weak rock strength-high altered heading should be applied the in-cycle shotcrete and didn't abandon the front without support for the long time.

Key words : Cut and fill; squeezing failure ; rubble material ; Convergent Confinement ; Professional Judgement

\section{A. PENDAHULUAN}

\section{A.1 Latar Belakang}

Tambang Ciurug merupakan area tambang paling besar dimana banyak terdapat heading dengan kadar tinggi. Tambang ini dibagi menjadi tiga baian yaitu Utara, Central, dan Selatan. Tambang Ciurug Central merupakan andalan untuk menopang produksi Au dari UBPE Pongkor. Namun, kondisi geoteknik batuan di lokasi tersebut berbanding terbalik dengan kadar Au nya. Tambang Ciurug Central didominasi kelas batuan III-V, beberapa lokasi dengan kadar Au sangat tinggi berada pada kelas batuan $\mathrm{V}$ yang membutuhkan perhatian geoteknik lebih.

Pada Februari - Mei 2018, diindikasikan ada potensi squeezing failure pada XC 662. Terbukti dengan telah dilakukannya tambahan perkuatan sebanyak 11 kali karena deformasi mayor pada penyanggaan shotcrete yang relatif sering. Analisis dasar merujuk pada tiga penyebab masalah yaitu :

- Environment : Massa batuan lunak, mempunyai daya dukung yang sangat rendah, nilai kuat tekannya lebih kecil daripada stress disekeliling terowongan

- Material : Penyanggaan Shotcrete tidak dapat menahan pergerakan massa batuan

- Method

: Metode analitik menggunakan konsep Beban Batuan vs Penyanggaan tidak bisa menjawab peristiwa deformasi yang berulang di lokasi penelitian

Kemudian dilakukan pendekatan konsep beban mati (dead load) yang pada umumnya digunakan dengan memperhitungkan beban runtuhan berkisar 60-70 ton dan kekuatan penyangaan yaitu menggunakan shotcrete setebal $10-15 \mathrm{~cm}$. Hasilnya sebagian tetap mengalami deformasi, selain itu dimensi stope juga mengecil dari lebar bukaan 3-3,5m menjadi kurang dari 2,6m.

Kasus lain pada heading XC 662.1 yaitu upaya penembusan pada zona ambrukan. Secara kondisi batuan memilki kesamaan dengan XC 662 dan memang sebelumnya heading ini pernah dilakukan upaya penyangaan. Kondisi massa batuan yang sangat buruk menyebabkan upaya penyanggaan gagal dan terjadi failure tanpa adanya kecelakaan. Hasilnya heading tersebut kemudian ditinggalkan. Pada bulan Maret 2019, upaya penembusan ambrukan dilakukan kembali. Analisis dasar merujuk pada tiga penyebab masalah yaitu

- Environment : Kondisi massa batuan sudah ambruk, kekuatan intact rock sangat lemah, batuan sudah tidak insitu, banyak terdapat rembesan air

- Material : Penyanggan menggunakan shotcrete + split set tidak mampu menahan beban

- Method : Metode analitik dan empiris tidak dapat dilakukan karena kondisi batuan yang sudah ambruk 
Dari hasil analisis dasar penyebab masalah ini, tim Geoteknik mencoba melakukan observasi lapangan guna mencari pendekatan yang paling tepat untuk melakukan penanganan ambrukan ini.

\section{A.2. Tujuan}

Tujuan pada penelitian ini adalah untuk menyelesaikan masalah geoteknik pada kondisi batuan yang sangat buruk (very weak rock strength dan high altered) dan upaya penembusan lokasi ambrukan pada tambang emas bawah tanah.

\section{A.3. Pendekatan Pemecahan Masalah}

Dalam kasus ini dilakukan dua pendekatan yang berbeda. Pendekatan pertama menggunakan metode analitik yaitu Convergent Confinement Method (CCM) untuk menangani heading yang memiliki kondisi batuan very weak rock strength dan high altered dengan potensi squeezing failure yang tinggi. Pendekatan kedua menggunakan pendekatan Professional Judgement yang direncanakan dengan matang dan aman tanpa mengabaikan faktor keselamatan (keselamatan manusia dan alat pada lokasi ambrukan. Dua pendekatan yang tidak banyak digunakan ini akan diperkenalkan karena sudah terbukti berhasil untuk menangani kasus geoteknik pada lokasi dengan kondisi batuan buruk dan ambrukan.

\section{B. METODOLOGI PENELITIAN}

\section{B.1 Convergent Confinement Method (CCM)}

Daemen (1977) memperkenalkan konsep penentuan kebutuhan penyanggaan untuk masalah-masalah terowongan yang diakibatkan stress (tegangan), baik pada massa batuan competent maupun incompetent. Konsep tersebut dinamakan rock support interaction curve atau convergence confinement method (CCM), dimana konsep tersebut memperhitungkan kondisi-kondisi dibawah ini,

- massa batuan (sifat fisik dan mekanik),

- besarnya tegangan disekitar terowongan,

- perpindahan (convergence) massa batuan disekitar terowongan,

- daya dukung penyanggaan, baik kekuatan maupun nilai ijin regangan penyanggaan.

Metoda CCM ini memperlihatkan bahwa semakin besar perpindahan batuan pada titik tertentu, maka semakin kecil tekanan batuan yang harus disangga oleh Penyanggaan. Gambar 1, memperlihatkan kurva 2 dimensi dari displacement (perpindahan batuan; absis) dengan support pressure (tekanan batuan; ordinat), dimana keduanya mempunyai hubungan berbanding terbalik. Pada gambar tersebut, jika penyanggaan di-instal pada titik D, akan terjadi 3 kemungkinan menurut Daemen (1977), antara lain :

1. D-CB; too stiff. Penyanggaan terlalu kaku, harus dapat menopang stress yang relative tinggi.

2. D-EF; optimum design. Penyanggaan optimal karena relative tidak terlalu kaku. Penyanggaan dapat meregang dan mengurangi tekanan batuan pada level tertentu.

3. D-H; too flexible. Pada titik $\mathrm{H}$ massa batuan mulai terjadi loosening dan tekanannya malah akan meningkat seiring berlangsungnya perpindahan batuan. Penyanggaan yang terlalu fleksible sangat berbahaya bagi kegiatan operasional. 


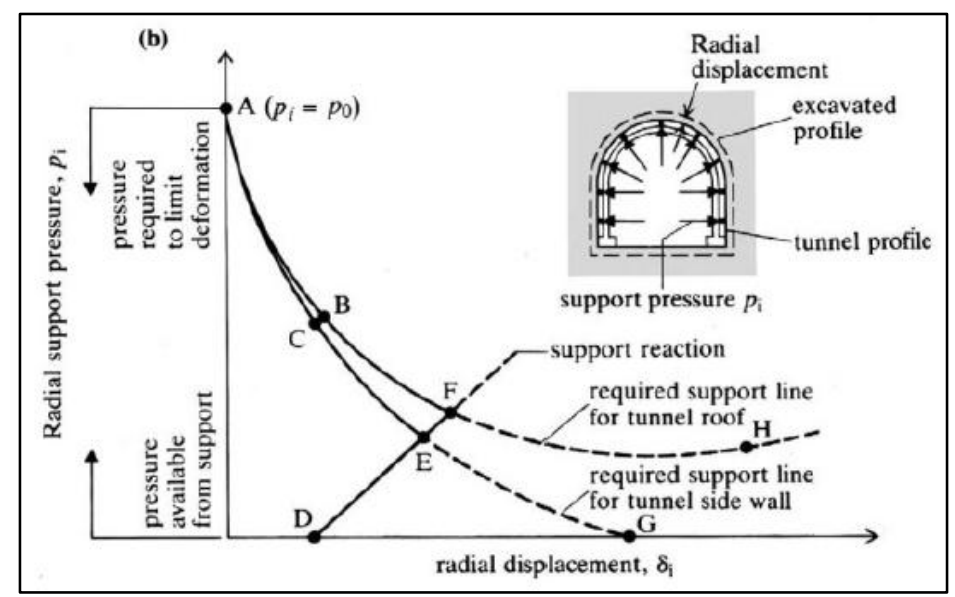

Gambar 1. Kurva interaksi massa batuan dengan penyanggaan (Daemen, 1977)

\section{B.2 Pendekatan Professional Judgement}

Penembusan ambrukan batuan yang terjadi pada XC 662.1 merupakan kasus yang sulit dipecahkan dengan metode analitik, sehingga tim Geoteknik UBPE Pongkor menggunakan pendekatan Professional Judgement, Safe, and Well-Planned Method. Pendekatan ini dilakukan dengan menggunakan asumsi beban yang harus di sangga setiap akan melakukan penyanggaan atau mirip dengan konsep Beban Mati (Dead Load) yang pada umumnya banyak digunakan di tambang bawah tanah. Asumsi ini muncul dari hasil observasi lapangan dengan mempertimbangkan beberapa aspek yaitu :

1. Besar beban runtuhan, diperoleh dari melihat rongga yang terbentuk di lapangan

2. Kekuatan penyanggaan, diperoleh dari hasil uji laboratorium material penyanggaan

3. Stand-up time, diketahui bahwa sebuah material lepas tidak dapat berdiri dalam waktu yang lama

4. Teknis operasional, hal ini perlu diperhatikan karena jika terdapat kesalahan pada saat melakukan penggalian atau penyangaan dapat berakibat kegagalan

Pendekatan Professional Judgement ini dilakukan pada kasus tertentu saja dimana kondisi massa batuan sangat sulit untuk dilakukan pemodelan numerik atau pendekatan empiris, sehingga pada pelaksanaannya perlu pengambilan keputusan yang matang.

\section{HASIL DAN PEMBAHASAN}

\section{C.1. Rekayasa geoteknik pada heading XC 662}

Penulis beserta tim mencoba mengaplikasikan teori ini untuk melakukan back-analysis terhadap apa yang terjadi di lapangan. Hasil ujicoba tersebut dapat dilihat pada Gambar 2. Terlihat bahwa FS penyanggaan hanya 1.02 . Hal ini dikarenakan penyanggaan dipasang pada saat regangan batuan $=0 \%$. Secara operasional, berdasarkan pengalaman empiris UBPE Pongkor, kondisi massa batuan lunak jika tidak segera di support akan cepat ambruk sebelum tersangga, sehingga kami selalu menyemprotkan Shotcrete segera (in-cycle) setelah terowongan di ekskavasi. Kami interpretasikan, kegiatan Shotcrete in-cycle ini secara operational's best practice berhasil menahan pergerakan terowongan supaya tidak ambruk, namun secara konsep CCM tidak menguntungkan karena penyanggaan yang dipasang terlalu dini dan inilah yang menyebabkan tekanan batuan yang harus disangga tinggi. Tidak heran kondisi seperti ini membuat sebagian segmen terowongan di XC $662 \mathrm{C}$ ke S ter-deformasi. Nilai FS = 1.02 tersebut menurut pendapat Penulis sangat riskan, karena jika terowongan tersebut terkena gempa atau 
terkena stress tambahan lain dari terowongan-terowongan disekitarnya maka nilai FS pasti menurun, tidak aneh jika penyanggaan banyak terdeformasi.

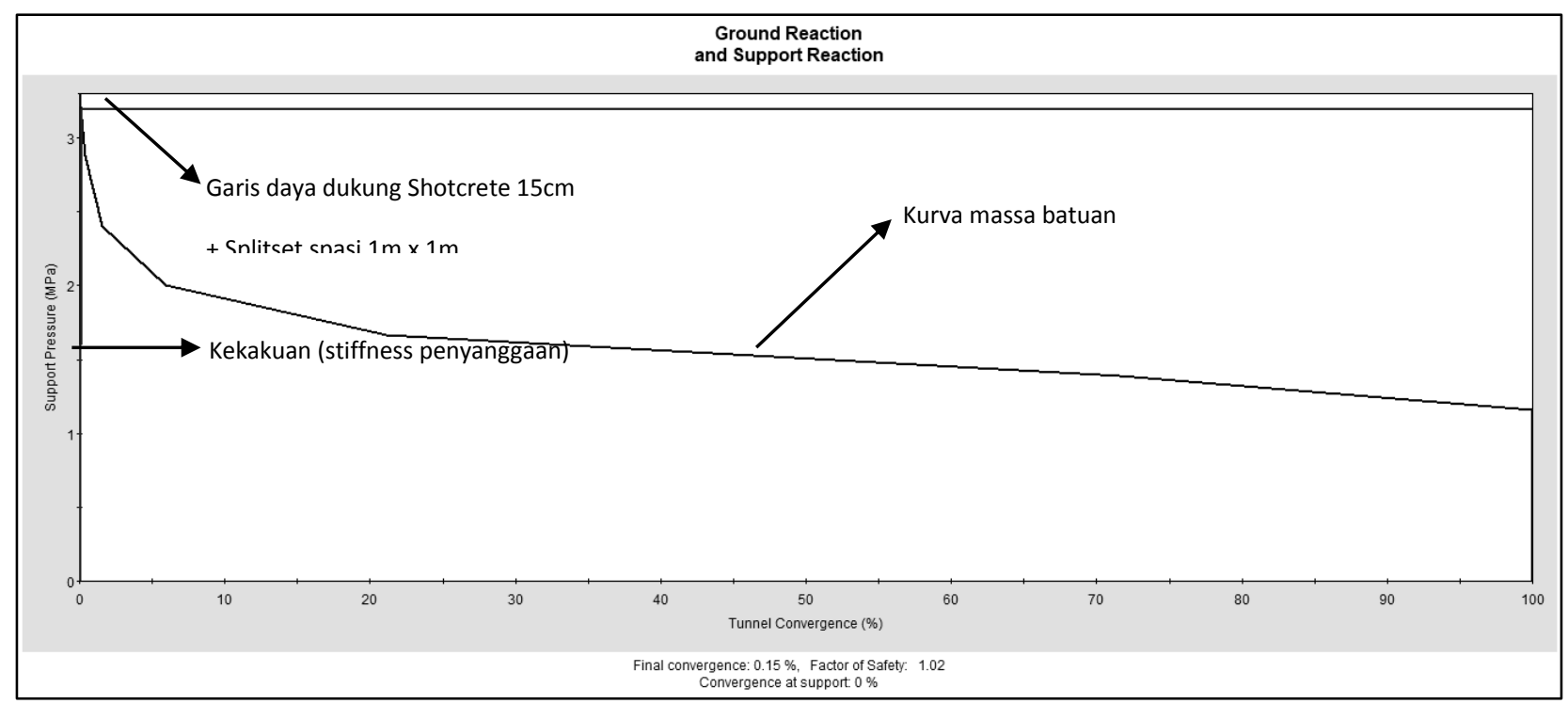

Gambar 2. Kurva reaksi massa batuan dengan penyanggaan di XC 662 C ke S L.600 CU saat regangan massa batuan $=0 \%$. FS terowongan $=1.02$.

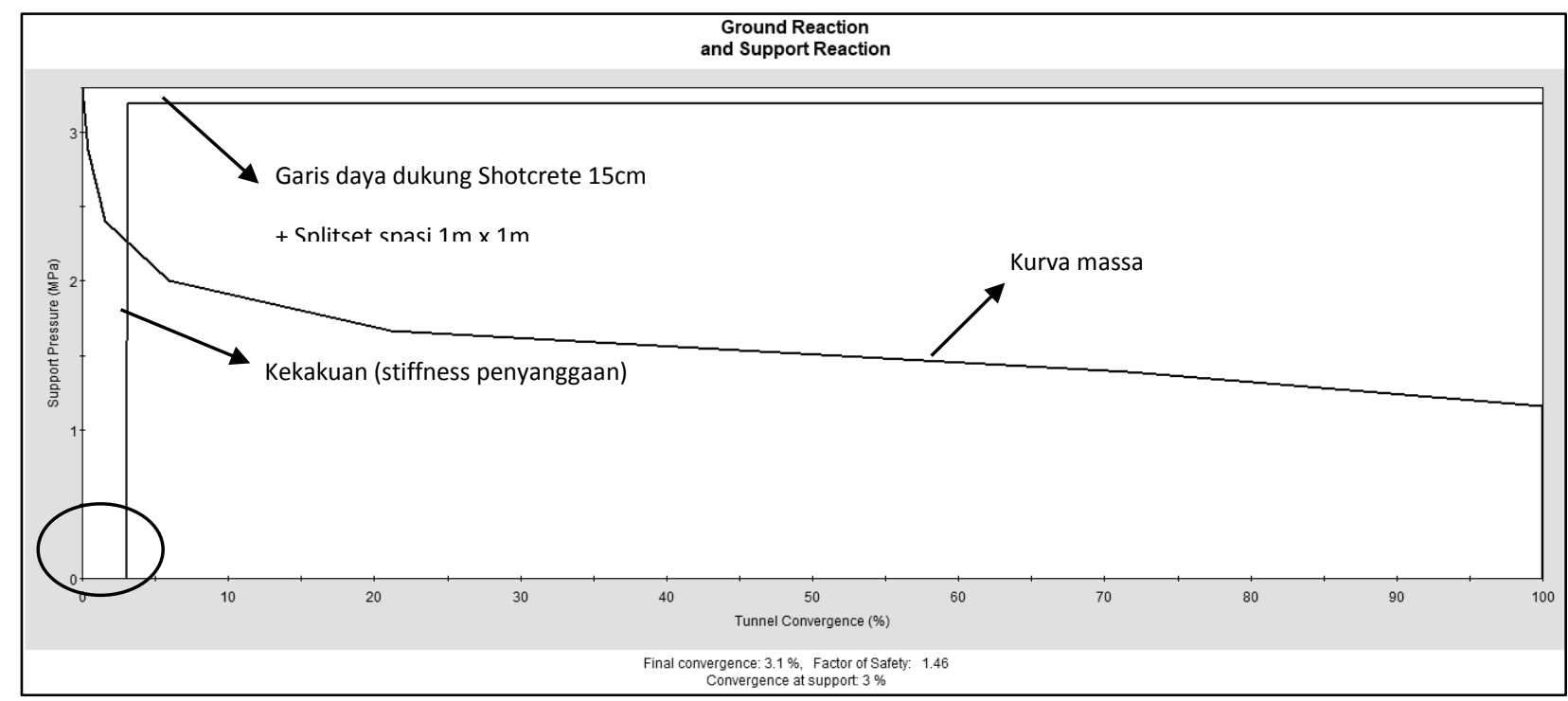

Gambar 3. Kurva reaksi massa batuan dengan penyanggaan di XC 662 C ke S L.600 CU saat regangan massa batuan $=3 \%$. FS terowongan $=1.46$.

Pada Gambar 3, terlihat bahwa nilai FS $=1.46$. Dengan daya dukung penyanggaan yang sama dengan Gambar 2, disaat perpindahan massa batuan di level 3\%, maka tekanan batuan yang harus disangga lebih kecil dibandingkan dengan Gambar 2, sehingga praktis nilai FS penyanggaan naik. Nilai perpindahan 3\% di dapat dari perbandingan antara perpindahan yang terukur di lapangan dengan radius terowongan. Selama massa penambangan sudah mencapai 6 bulan, yaitu pada awal bulan Mei 2018, perpindahan yang terjadi di lapangan maksimal $41.96 \mathrm{~mm}$, dengan radius terowongan $1500 \mathrm{~mm}$. Penulis menginterpretasikan bahwa keberhasilan sebagian segmen penyanggan tidak terdeformasi ulang adalah karena tekanan yang disangga oleh penyanggaan baru lebih kecil dari daya dukung 
yang disediakan penyanggaan. Tekanan yang lebih kecil tersebut dihasilkan oleh pergerakan massa batuan pada level tertentu. Secara operasional, permasalahan penyanggaan pada lokasi squeezing ground harus dipasang dengan segera karena dikhawatirkan akan ambruk sebelum penyanggaan terpasang. Delay penyanggaan bukan solusi untuk menunggu perpindahan massa batuan berada pada level tertentu sehingga tekanan batuan yang harus disangga mengecil. Solusinya, penulis membuat asumsi, interpretasi, dan perhitungan sederhana sebagai berikut :

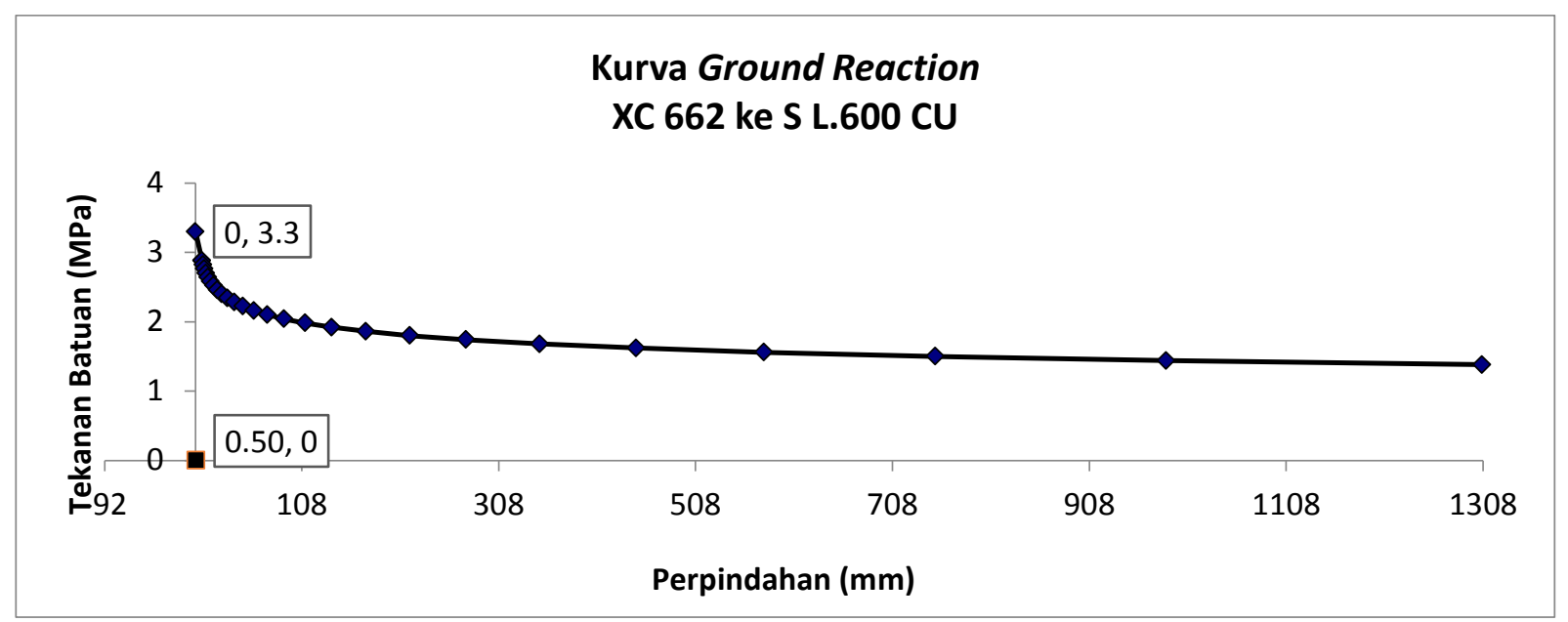

Gambar 4. Kurva reaksi massa batuan dengan penyanggaan di XC 662 C ke S L.600 CU

Tabel 1. Persamaan penentuan nilai maximum support dari shotcrete berdasarkan tebal shotcrete, umur, dan nilai UCS (Hoek, 2005)

\begin{tabular}{|c|c|c|c|c|c|}
\hline Support type & 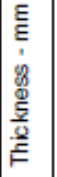 & $\begin{array}{l}\frac{n}{0} \\
\frac{\pi}{0} \\
\dot{8} \\
8\end{array}$ & $\begin{array}{l}\frac{\pi}{2} \\
\dot{0} \\
\stackrel{0}{\supset}\end{array}$ & 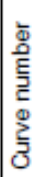 & $\begin{array}{l}\text { Maximum support } \\
\text { pressure } p_{\text {imax }}(\mathrm{MPa}) \text { for a } \\
\text { tunnel of diameter } D \\
\text { (metres) }\end{array}$ \\
\hline $\begin{array}{l}\text { Concrete or shotcrete } \\
\text { lining }\end{array}$ & $\begin{array}{l}1 \mathrm{~m} \\
300 \\
150 \\
100 \\
50 \\
50 \\
50\end{array}$ & $\begin{array}{c}28 \\
28 \\
28 \\
28 \\
28 \\
3\end{array}$ & $\begin{array}{l}35 \\
35 \\
35 \\
35\end{array}$ & 25 & $\begin{array}{l}p_{i \max }=57.8 D^{-0.92} \\
p_{i \max }=19.1 D^{-0.92} \\
p_{i_{\max }}=10.6 D^{-0.97} \\
p_{i \max }=7.3 D^{-0.98} \\
p_{i_{\max }}=3.8 D^{-0.99} \\
p_{i \max }=1.1 D^{-0.97} \\
p_{i_{\max }}=0.6 D^{-1.0}\end{array}$ \\
\hline
\end{tabular}

Dari hasil kurva ground reaction, Shotcrete in-cycle diasumsikan membuat penyanggaan berada pada nilai perpindahan batuan yang sangat rendah. Terowongan stabil setelah ekskavasi sampai dengan pemasangan final support (shotcrete layer-2). Penulis mengasumsikan bahwa terowongan di XC $662 \mathrm{C}$ ke $\mathrm{S}$ disangga ketika perpindahan batuan masih elastik, yaitu maksimal di angka $0.5 \mathrm{~mm}$ dengan $(3,3 \%)$. Angka regangan $0.5 \mathrm{~mm}$ ini diasumsikan sebagai titik awal pemasangan penyanggaan agar terowongan tidak ambruk secara dini (Gambar 5, titik jingga bawah). Data menunjukan bahwa pada lokasi XC 662 C ke S L.600 CU, selama kurang lebih 6 bulan, pergerakan maksimal massa batuan di Stope ialah $41.96 \mathrm{~mm}$, atau regangan yang terjadi sebesar $2.80 \%$.Maka dari itu, harus dicari penyanggaan yang mempunyai nilai stiffness rendah namun mempunyai daya dukung tinggi. 
Penyanggaan tersebut harus dapat menahan perpindahan batuan sebesar $41.46 \mathrm{~mm}$. Nilai rentang tekanan batuan pada rentang nilai perpindahan dari 0.5-41.96 $\mathrm{mm}$ adalah 3.2-2.2 Mpa. Jika menggunakan shotcrete, deformasi maksimal hanya $9 \mathrm{~mm}$ atau maximum strain $=0.15 \%$ (Wattimena, 2010), sehingga dibutuhkan shotcrete setebal 300mm (max support pressure $=4,79 \mathrm{MPa}$ ) untuk mencapai $\mathrm{FS}=1,7$ (tekanan batuan 2,8 $\mathrm{MPa}$ ) dan ini tidak practicable di lapangan. Contoh jika mengaplikasikan shotcrete dengan tebal $150 \mathrm{~mm}$ hanya mampu memberikan support pressure sebesar 2.46 Mpa sehingga tidak cukup untuk menahan tekanan batuan (2.80 Mpa), namun dapat menahan tekanan batuan setelah terjadi perpindahan batuan sejauh $41.96 \mathrm{~mm}$ (tekanan batuan pada perpindahan $41.96 \mathrm{~mm}=2.2 \mathrm{Mpa}$ ). Oleh karena itu, untuk mendapatkan penyanggaan dengan spesifikasi Maximum strain $41.46 \mathrm{~mm}$ atau $2.8 \%$ dan Support pressure min. 2.2 Mpa, dengan batasan desain penyanggaan menurut Hoek (2005) adalah :

Disaat melakukan pemasangan multiple support pada satu model, maka :

- Maximum Support Pressure dikumulatifkan dari semua jenis penyanggaan yang terpasang

- Maximum Average Strain di rata-rata untuk semua penyanggaan yang terpasang

Dimana penyanggaan Shotcrete memiliki spesifikasi mekanis sebagai berikut :

- Maximum strain Shotcrete $=9 \mathrm{~mm}$ atau $0.15 \%$

- $\quad$ Support pressure Shotcrete dengan tebal $150 \mathrm{~mm}=2.46 \mathrm{Mpa}$

Maka Penulis mengkombinasikan penyanggaan Shotcrete dengan penyanggaan yang memiliki daya dukung sebagai berikut :

Kebutuhan cumulative strain dari kombinasi penyanggaan $=$

- $\quad$ Maximum Average Strain $=\frac{\text { (strain shotcrete }+ \text { strain penyanggaan baru }}{2}$

- Maximum Average Strain $\geq$ kebutuhan strain $(2.8 \%)$

- $\quad$ Strain penyanggaan baru $=(2 \times \mathbf{2 . 8} \%)-\mathbf{0 . 1 5} \%=\mathbf{5 . 4 5} \%$

Hasil pencarian penyanggaan yang memiliki tingkat strain $=5.45 \%$ menyimpulkan bahwa hal tersebut dapat disediakan oleh penyanggan Cable Bolt dengan diameter $28 \mathrm{~mm}$ yang memiliki tingkat maximum strain $=5 \%-7 \%$ sebelum putus.

Tabel 2. Spefisikasi teknis dari Cable Bolt merek TG Bolt (Sumber : Jennmar Hard Rock Catalouge, 2014)

\begin{tabular}{ccccc}
\hline \multirow{2}{*}{ Strand Diameter } & $\begin{array}{c}\text { Typical Strand Yield } \\
\text { Strength }\end{array}$ & \multicolumn{2}{c}{ Typical Breaking Load } & \multicolumn{2}{c}{$\begin{array}{c}\text { Elongation at Strand } \\
\text { Failure }\end{array}$} \\
\cline { 3 - 4 } & & Strand & Strand at B\&W & \\
\hline \multirow{2}{*}{$28 \mathrm{~mm}$} & $568 \mathrm{kN}$ & $635 \mathrm{kN}(63 \mathrm{ton})$ & $540 \mathrm{kN}(55 \mathrm{ton})$ & $5-7 \%$ \\
\hline
\end{tabular}

Perbandingan antara penyanggaan sebelum (Shotcrete $150 \mathrm{~mm}+$ Splitset spasi $1 \mathrm{~m} \times 1 \mathrm{~m}$ ) dengan konsep penyanggaan baru yang diusulkan Penulis (Shotcrete $150 \mathrm{~mm}+$ TG bolt spasi $1.5 \mathrm{~m} \times 1.5 \mathrm{~m}$ ) dapat terlihat pada grafik dibawah ini, 


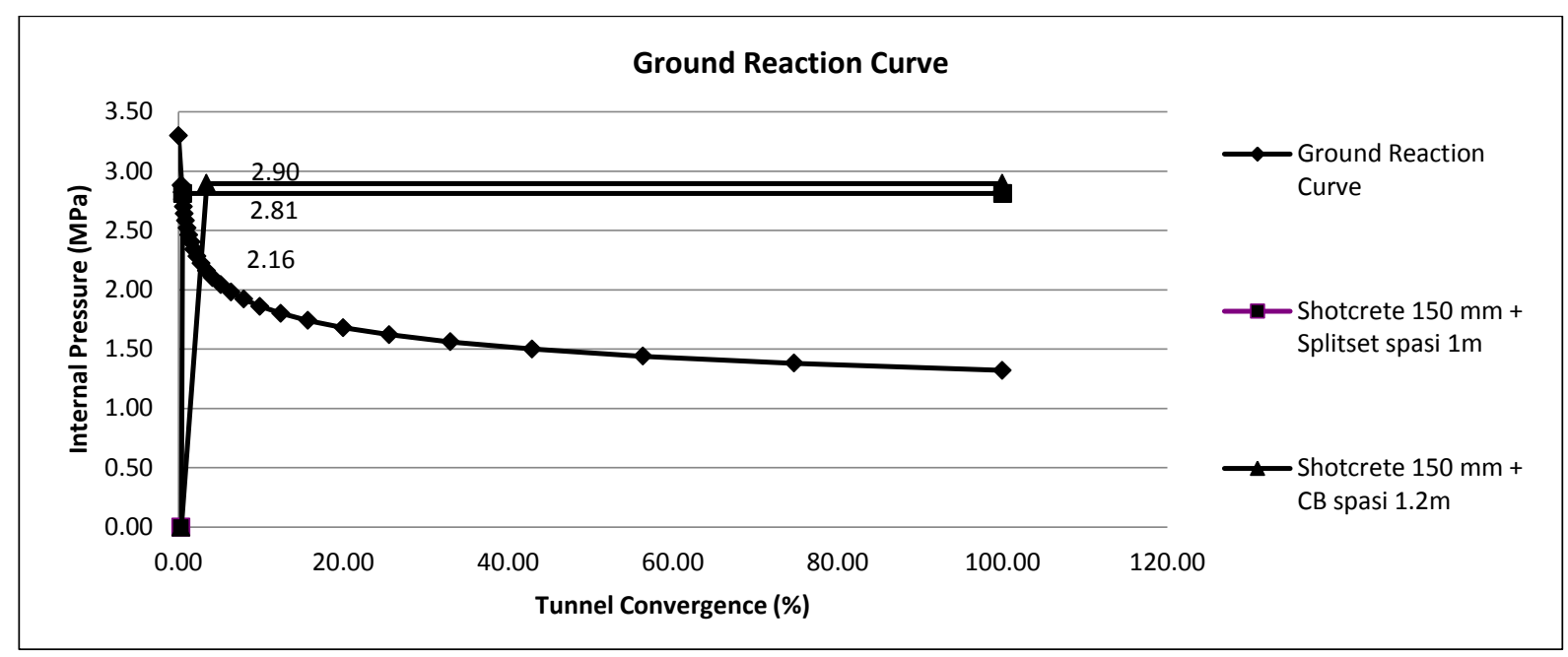

Gambar 5. Ground Reaction Curve di lokasi XC 662 C ke S L.600 CU

- $\mathrm{FS}=1.02$ untuk penyanggaan Shotcrete $150 \mathrm{~mm}+$ Splitset spasi $1 \mathrm{~m} \times 1 \mathrm{~m}$. Max Support pressure yang disediakan penyangga $=2.81 \mathrm{Mpa}$ untuk menahan stress $=2.76 \mathrm{Mpa}$.

- $\mathrm{FS}=1.34$ untuk penyanggaan Shotcrete $150 \mathrm{~mm}+$ TG Bolt spasi $1.5 \mathrm{~m} \times 1.5 \mathrm{~m}$. Max Support pressure yang disediakan penyangga $=2.90 \mathrm{Mpa}$ untuk menahan stress $=2.16 \mathrm{Mpa}$.

Solusinya adalah mencoba mengkombinasikan antara shotcrete dengan TG Bolt (Cable Bolt) sehingga kestabilan terowongan dapat tercapai dan meminimalisir potensi delay produksi di lapangan.

\section{C.2. Rekayasa geoteknik pada heading XC 662.1}

Kondisi heading XC 662.1 secara geoteknik disebut failure condition, dimana batuan sudah mengalami ambrukan. Namun, upaya penembusan tetap dilakukan dengan rekayasa menggunakan pendekatan professional judgement. Observasi lapangan dilakuan untuk mengetahui perkiraan beban runtuhan yang perlu disangga dengan melihat volume rongga yang terbentuk, kekuatan dan karakter intact rock untuk menentukan jenis material penyanggaan, kuantitas air yang keluar dan teknis operasional. Hasil dari observasi lapangan didapatkan rekomendasi support menggunakan kombinasi alat sebagai berikut

\section{Shotcrete}

Shotcrete yang digunakan memilki kekuatan 1 jam mencapai $1 \mathrm{MPa}$. Penggunaan shotcrete dilakukan secara in-cycle untuk menghindari ambruknya heading setelah dilakukan ekskavasi. Hasil rekam data menunjukkan heading ambruk setelah 30 menit dibiarkan tanpa penyangaan.

2. $\quad$ Pipa spilling

Pipa spilling memilki spesifikasi $\mathrm{d}=2$ inch ; panjang $=6 \mathrm{~m}$. Material ini digunakan sebagai payung forepolling dan pemadat material ambrukan. Pemasangan pipa forepolling dilakukan dengan "ditusukkan" ke dalam material ambrukan hingga mencapai insitu rock melewati spasi Hbeam.

\section{Grouting pipe}

Grouting pipe atau pipa yang disuntikan material grouting bertujuan untuk menambahkan kuat geser dari pipa sehingga saat terkena ambrukan material tidak mudah patah. Kegunaan lainnya untuk merekatkan material ambrukan sehingga nilai sudut geser dalam dari material akan naik. 
Tabel 3. Spesifikasi Pipa MS spilling dan jika ditambahkan material grouting

\begin{tabular}{|c|c|c|c|c|c|c|c|c|c|c|c|c|c|c|c|}
\hline \multirow{2}{*}{ Type of Pipe } & \multicolumn{6}{|c|}{ Spilling Pipe Stre } & \multicolumn{3}{|c|}{ Cement Grout Streng } & Total & & \multirow{2}{*}{$\begin{array}{c}\text { Span } \\
\text { (m) }\end{array}$} & \multirow{2}{*}{$\begin{array}{c}\mathbf{L} \\
(\mathbf{m})\end{array}$} & \multirow{2}{*}{$\begin{array}{c}\text { BJ } \\
(\mathbf{t} / \mathbf{m} 3)\end{array}$} & \multirow{2}{*}{$\begin{array}{c}\text { W RMR } \\
\text { (Ton) }\end{array}$} \\
\hline & & & & & & & & & & & & & & & \\
\hline & 3747 & 0,05 & 0,004 & 0,042 & 0,00058 & 7,80 & 120 & 0,0014 & 0,1 & $8,($ & & 4,6 & 1,5 & 2,2 & 69,8 \\
\hline
\end{tabular}

\section{Bantalan kayu stapling}

Pemasangan kayu stapling berfungsi sebagai bantalan H-beam dan pipa spilling dari material ambrukan yang jatuh, sehingga pipa dan H-beam tidak langsung bending jika terkena jatuhan boulder. Selain itu, fungus dari stapling untuk barrier dari material berukuran dibawah boulder yang rontok dari rongga.

5. Material ambrukan

Dalam metode ini, material ambrukan berguna sebagai penguat heading sementara sebelum dipasang penyangga utama. Material ambrukan memilki berat jenis 2,1-2,3 gr/ $\mathrm{cm}^{3}$, jika material ini didorong ke area heading akan berfungsi menahan boulder yang akan jatuh.

6. H-beam

H-beam yang dipasang memilliki spesifikasi dimensi pxl $=4 \mathrm{~m} \times 4 \mathrm{~m}$ dengan spasi pemasangan setiap $1 \mathrm{~m}$. Beban maksimal yang dapat ditumpu adalah 30 ton setiap set Hbeam. Pemasangan $\mathrm{H}-$ beam dilakukan setiap penyanggaan liner sudah terpasang dengan baik.

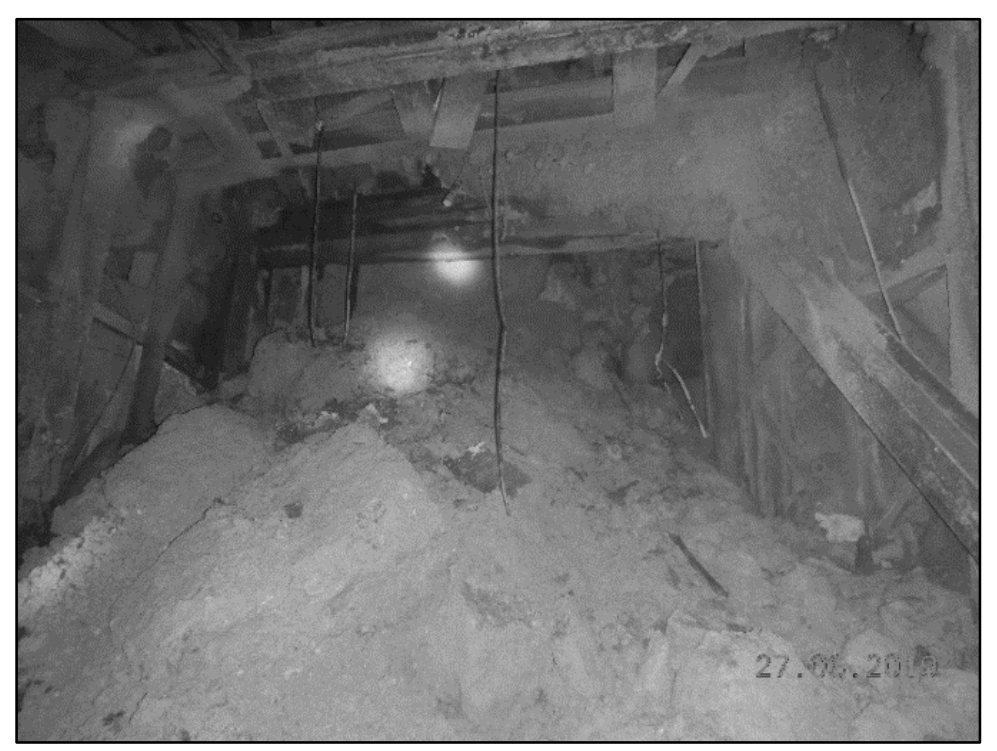

Gambar 6. Kenampakan heading XC 662.1 yang ambruk

Berikut adalah kenampakan heading XC 662.1 yang ambruk (Gambar 6). Penulis akan menjelaskan langkah penanganan ambrukan dengan pendekatan professional judgement :

1. Lakukan pengukuran rongga yang terbentuk diatas Hbeam paling depan untuk memperkirakan volume rongga.

2. Lakukan mucking out material ambrukan yang menutupi heading namun hanya sebagian saja. Sisa dari material ambrukan yang tidak di mucking digunakan sebagai muck level yang nantinya akan berfungsi sebagai pondasi untuk mendorong lagi material ambrukan yang di mucking out 
3. Dorong material ambrukan yang di mucking out hingga hampir menutupi rongga di depan Hbeam

4. Instalasi shotcrete di bagian front dan roof setebal $5-10 \mathrm{~cm}$, shotcrete harus menutupi material ambrukan yang sudah di dorong tadi

5. Setelah shotcrete kering dan mencapai kekuatan $1 \mathrm{MPa}$, pasang pipa spilling sebagai forepolling dengan cara ditusukkan dari atas cap Hbeam ke arah front dengan sudut kemiringan $40^{\circ}$, spasi pipa spilling sebesar $30 \mathrm{~cm}$. Pola pemasangan pipa dimulai dari rib kiri - atas - rib kanan dan dirapatkan untuk menahan boulder yang jatuh dari rongga.
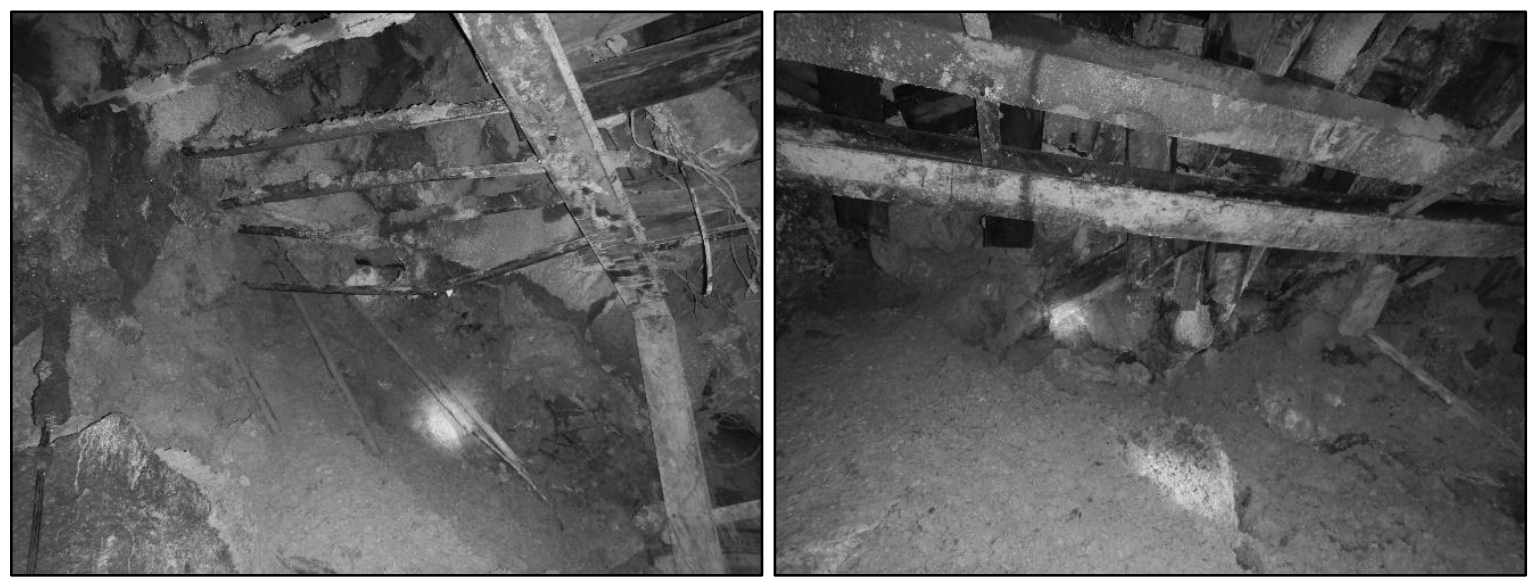

Gambar 7 (kiri). Pipa spilling yang di grouting dipasang dengan spasi 30-40 cm dapat menahan material ambrukan dari rongga; (kanan) Kayu stapling sebagai bantalan pipa spilling yang terkena ambrukan boulder besar

6. Pasang kayu stapling diatas pipa forepolling sebagai bantalan forepolling dari boulder yang berpotensi jatuh dari rongga

7. Untuk memperkuat forepolling pipa spilling, lakukan injeksi grouting ke dalam badan pipa spilling. Grouting ini diharapkan juga dapat merekatkan batuan-batuan yang sudah lepas, namun hasilnya kurang baik karena batuan-batuan yang ambruk bertekstur basah dan semen tidak dapat menempel

8. Saat forepolling sudah terpasang dengan baik, upaya kemajuan mulai dilakukan. Proses penggalian material ambrukan yang tadi sudah di shotcrete dimulai dari bagian tengah muka ke bawah. Penggalian ini disebut penggalian pertama.

9. Setelah penggalian pertama selesai, langsung lakukan instalasi shotcrete secara in-cycle agar material ambrukan tidak turun

10. Setelah shotcrete kering, penggalian berikutnya dilakukan dari bagian tengah muka ke atas. Penggalian ini disebut penggalian kedua. Lakukan instalasi shotcrete segera setelah penggalian kedua selesai.

11. Material pada front yang sudah di shotcrete akan padat. Pada tahap ini, pemasangan Hbeam dapat dilakukan dengan spasi $1 \mathrm{~m}$.

12. Evaluasi dan pemantauan support rutin dilakukan untuk mencegah terjadinya kerusakan pada penyanggaan

Upaya penembusan sepanjang kurang lebih 5m dilakukan selama 1 bulan lamanya. Kondisi heading saat ini tersusun atas batuan insitu dan dapat dipasang penyanggaan standar (mesh+bolt+OSRO+shotcrete 10-12 cm). Pemantauan deformasi support tetap dilakukan karena dikhawatirkan memiliki karakter failure yang sama seperti XC 662. 


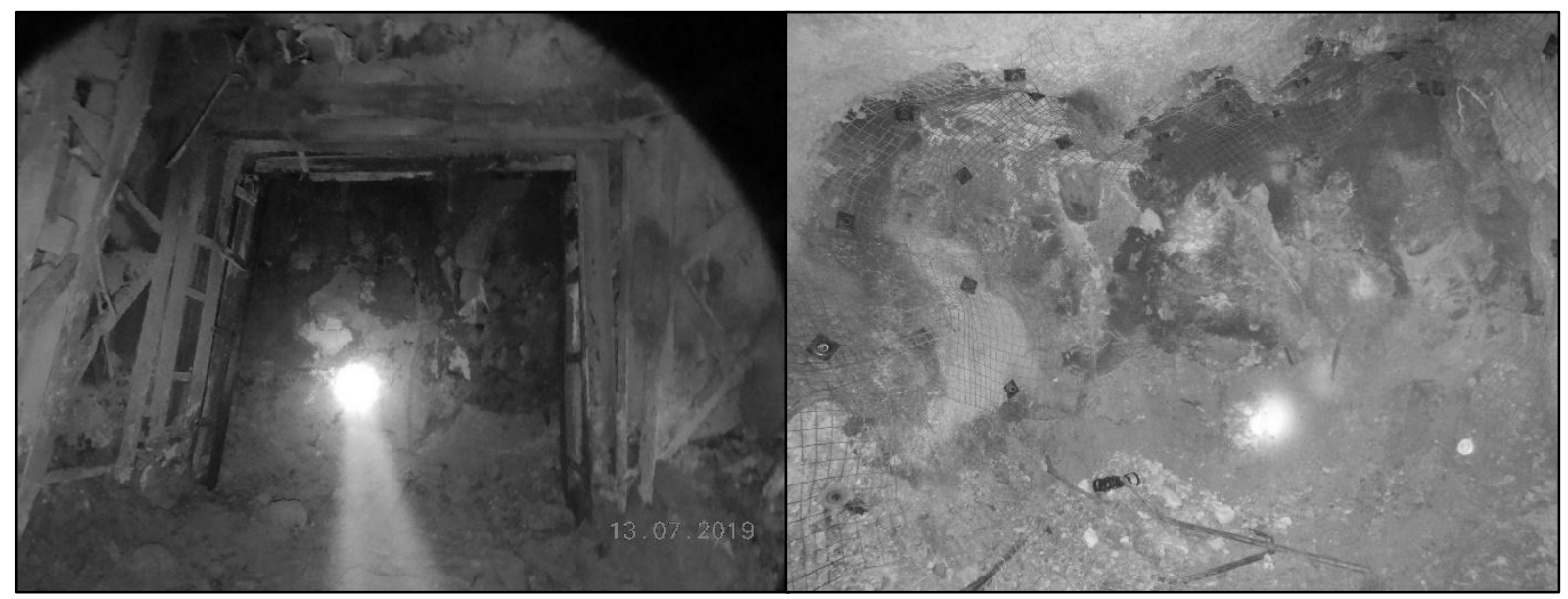

Gambar 8 (kiri). Kondisi heading XC 662.1 beberapa hari setelah berhasil dilakukan penembusan ambrukan; (kanan). Kondisi heading XC 662.1 saat ini menggunakan penyanggaan standar

\section{KESIMPULAN}

- Pendekatan metode Convergent Confinement dapat mengetahui semakin kecil perpindahan massa batuan maka semakin besar tekanan batuan yang harus disangga oleh penyanggaan, sehingga kami interpretasikan bahwa keberhasilan penyanggaan baru tidak terdeformasi ulang adalah akibat nilai tekanan batuannya sudah lebih kecil. Kombinasi antara Shotcrete dengan TG Bolt (Cable Bolt) sehingga kestabilan terowongan dapat tercapai dan meminimalisir potensi delay produksi di lapangan.

- Upaya penembusan ambrukan dengan professional judgement dapat dilakukan dengan adanya kombinasi antara geoteknik dan operasional dalam pelaksanaannya. Penyanggaan forepolling pipa-grouting, kayu stapling, shotcrete in-cycle, dan Hbeam dapat mengatasi beban ambrukan yang ada, dengan catatan kecepatan kemajuan heading tidak lebih dari $1 \mathrm{~m}$ per kemajuan.

\section{DAFTAR PUSTAKA}

Daemen, J.J.K. (1977). Problems in Tunnel Support Mechanics. Undeground Space, hal 163-172 Hoek, E. (2000). Big Tunnel in Bad Rock. Journal of ASCE Geotechnical and Geoenviromental Engineering, hal 5-9

Data Spesifikasi Teknis Cable Bolt merk TG Bolt didapatkan dari Jennmar Hard Rock Catalogue, data diperoleh dari situs internet : http://www.jennmar.com/ProductCategory-Coal-Mining?search keywords=Tg+bolt. Diunduh pada tanggal 14 September 2019. 
PROSIDING TPT XXVIII PERHAPI 2019 